\title{
The Role of Police to Reduce and Prevent Cyber- bullying Crimes in Indonesia
}

\author{
Abdul Sakban ${ }^{1 \mathrm{a}}$, Sahrul ${ }^{2 b}$, Andi Kasmawati ${ }^{3 \mathrm{c}}$, Heri Tahir ${ }^{3 \mathrm{~d}}$ \\ ${ }^{1}$ Department of Social Science and Education, University Muhammadiyah of Mataram, Indonesia \\ ${ }^{2}$ Department of Law, University Muhammadiyah of Mataram, Indonesia \\ ${ }^{3}$ Department of Social Science, the University State of Makassar, Indonesia \\ a sakban.elfath@yahoo.co.id, ${ }^{b}$ sahrul25@gmail.com, ${ }^{\mathrm{c}}$ kasmawatiamri@yahoo.co.id, ${ }^{\mathrm{d}}$ heri.tahir@yahoo.co.id
}

\begin{abstract}
The impact of cyber-bullying crime causes victims to be harassed, intimidated, threatened, insulting someone else's self-esteem resulting in hostility between them both through the internet medium. This phenomenon is interesting to explain in depth. The goal to be achieved in this article is to explain the role of the police to reduce and prevent cyber-bullying crimes in Indonesia. The method used in this research is qualitative with analytic description approach and case study. Data collection using literature study, interview, document analysis. Data analysis using literature and conceptual study techniques. The result of the study that the role of police to reduce and prevent cyber-bullying crimes in Indonesia, can be done the following steps: 1) socialization to educational institution, institution, campus and society regularly, 2) internet ethics, the role of parents should be more intensively supervise the development of children against the influence of the internet media, police officers routinely conduct "anti-bullying" (stop bully) campaigns in schools, campuses/institutions and communities, and involving social organizations to monitor the circulation of cyberbullying crime. So the preemptive action of the police in doing cyber-bullying prevention cannot be done alone (police) but must be mutual cooperation with various the stakeholders.
\end{abstract}

Keywords-Role; Police; Reduce; Prevent,; Cyber-bullying

\section{INTRODUCTION}

Cyber-bullying is an abnormal act committed through electronic media. This crime causes victims to be ostracized, harassed, ambiguous, intimidated, threatened, offended/ insulting others' pride resulting in hostility between them through internets and mobile technology services such as mobile phones and text messages (SMS). Cyber-bullying is defined as deliberate behavior by constantly scavenging others by using computers, cell phones and other electronic devices (Hinduja \& Patchin, 2010).

This cyber-bullying crime includes criminal offenses committed by a person through short messages using internet media and informatics and electronic technology to insult and harass others in writing, images, symbols and other animations. Message or short article posted on account twitter, facebook, Instagram, line, and what shape private or peer and even public. The existence of bully writing can cause someone offended, angry, and proven to have many similar cases for the perpetrator's to prison, for example, Ropi Yatsman, Riza Ali Zain, Sri Rahayu, and Muhammad Arsyad Assegaf, they are considered to have violated the ethics of communication in the internet media.

Observations show that around $42 \%$ of children experience cyber-bullying $35 \%$ of children are threatened online, 58\% of children admit that they often experience online harassment and humiliation and 58\% of children admit they do not report to their parents about the cyberbullying they are experiencing (Ryan \& Curwen, 2013). Other studies in the literature show that there are $10 \%$ of the participants who are 17-25 age groups appear to be the victims of cyber-bullying (Brack \& Caltabiano, 2014). There were $32.4 \%$ of participants stated that they had been bullied by at least from SMS, e-mail and social networking at Texas University (Crosslin \& Crosslin, 2014). There were $57 \%$ of the students doing cyber-bully crime less than 4 times, 29\% 4-5 times, $14 \%$ more than 10 times (Walker, Sockman, \& Koehn, 2011). While the study of female students who cyber-bullied, they mostly experience the seizure of accounts of others (hack), receiving unwanted sexual messages, some kind of harassment delivered through text messages and insulting remarks (Selkie, Kota, Chan, \& Moreno, 2015). Various cyber bullied phenomena above, interesting enough to be studied in depth, because this phenomenon is quite dynamic and badly need a solution to reduce negative impact to victim and society of another social media activist.

In relation to the cyber-bullying crimes committed in Internet media and technology, of course, many have been analyzed into various aspects, some are studying about the bullying actors having conceptual differences in committing crimes especially for young people in the 21 st century, and the study of this study has not led to the making of a policy is only quantitative data only (Randa, Nobles, \& Reyns, 2015). Cyber-bullying (via mobile and internet) only discuss cyber-bullying is only quantitative, does not consistently explain cyber differences with bullying from general aggression (Sittichai, 2013). There are analyzes about the behavior of cyber-bullying actors with the reactive behavior of cyber-bullying victim students, in the results of his study resulted there is an influence between cyber-bullying behavior with the 
reactive the behavior of a cyber-bullying student with significance $0,037<0,05$. The results of the analysis also explain several factors that cause the perpetrators to conduct cyber-bullying is 1) family factors, factors themselves and the environment also has a strong level of influence and significance. 2) the influence of digital protection, social protection, and self-factors also affect the behavior of victims (Pandie, 2016). But this study has not given a sanctions to the perpetrators or strategies to prevent cyber-bullying, so this study is still theoretical cyber-bullying.

Similarly, other research results explain the criminal rules of cyber-bullying crime. Whereas cyber-bullying in Indonesia is regulated in Article 27 of the Law on EIT Number 11 the Year 2008 and Number 19 the Year 2016, in the Act there are several actions including cyberbullying namely Flaming, Harassment, Impersonation, Outing, Trickery, Exclusion, Cyberstalking. The Electronic Transaction Information Act contains only elements of humiliation and threats, whereas other cyberbullying acts also often occur and become the first step of another criminal offense (Minin, 2018). In addition, cyberbullying crime prevention methods can be communicated by the police and teachers through the anti-bullying campaign strategy in educational institutions, this step is good enough because they have reached $97 \%$ and the activities are undertaken by teachers only reached $57 \%$, but the study has not described conceptually what approaches are used by police or teachers (Glasner, 2010).

Based on various studies and literature above, that their findings are more focused on the explanation of factors causing the behavior of perpetrators to commit cyberbullying criminal acts, the next still describes the cyberbullying case data is not explained in detail, then the others only analyze the criminal act about cyber-bullying by implementing the Act invite informatics of electronics technology, and some explain the prevention of cyberbullying involving the police in taking precautions. So the conclusion is that among them no one has analyzed the role of the police to reduce and prevent cyber-bullying crimes in Indonesia.

So this article is purely the original thoughts of the author, the novelty contained in this article focuses on the efforts of police precautions to reduce and prevent cyberbullying crime in the internet media. In this article, the theory used is the theory of cyber-bullying prevention according to Keller (Keller, 2012).

To prevent cybercrime can be done several steps that 1) if someone knows a target of cybercrime, immediately notify the family, friends, teachers, and superiors. Other steps: a) talking to people who are able to stop cybercrime. b) did not participate in activities that degrade and hurt others. c) exclusively for minors, let parents know the social media account keywords to avoid cyberspace harassment. 2) If a person is known to cyber-bullying to another person, then requires clarity that the offender understands what he is doing is wrong. Tips have undertaken in the activities, namely a) to educate how to use the internet is responsible (Hinduja \& Patchin, 2014). b) precautionary measures that need to be done is the socialization of the ITE Act and internet ethics (Rastati, 2016).

The contribution of science in this article is to produce alternative methods in reducing and preventing more victims of cyber-bullying, resulted in a humanist police action in preventing cyber-bullying crime by using socialization approach so that police performance is very good in serving the community. Thus, the purpose of this article is to describe the role of the police in reducing and preventing cyber-bullying crime in Indonesia.

\section{RESEARCH METHOD}

This research method uses qualitative research with analytical description approaches and case studies. The next step is to conduct a preliminary study in the provinces of West Nusa Tenggara, Bali, and South Sulawesi, and then conduct a literature study in the form of primary data and secondary data. Then to get valid cyber-bullying crimes: the researchers conducted interviews with a number of informants and informants, namely three special regional criminal directors, three special deputy criminal directors of the regional police and four special cybercrimes staff in the regional police in Indonesia, so the total number of research subjects that have been obtained are ten people from the three provinces.

For more details, cyber-bullying crime cases are analyzed according to the purpose of the study, then literature studies are conducted in relation to regulations and laws governing cyber-bullying crimes in Indonesia, as well as analyzing documents in the form of conversations on social media that have elements of cyber-bullying. After being analyzed, the final step is to explain conceptually and literature studies relating to the role of the police, policies and duties and authorities in taking precautions against cyber-bullying crimes in Indonesia.

\section{RESULT AND DISCUSSION}

\section{A. The development of the use of the Indonesian internet media and cyber-bullying crimes in Indonesia}

Indonesia is one of the most contributing countries in applying internet media start using facebook application, Twitter, Instagram, line, email, and what shape. In 1995 there were only 1 million sites on the internet. In 2010 the number has reached 1.97 billion (RI, 2014). Meanwhile, the report from the Association of Internet Service Providers Indonesia (APJII), noted there is an increase in internet users in Indonesia reached 88.1 million in 2014 with a penetration of $34 \%$ (Indonesia, 2015).

Indonesia goes into the top 10 Google+ user countries today. Indonesia's ranking is in 7 th place with 208,464 users or 1.82 percent of total Google+ users in the world. From the data seen also Google + social network users in Indonesia is able to defeat Google+ users in Mexico, Italy, and Spain. Indonesian people are able to get into the top 10 social social networking users in the world such as the use of Facebook rank 4 and the use of twitter Indonesia is able to enter the 5th rank and be able to beat other countries, other than that proved where Indonesia entered 
the largest country in the use of Google in the world (Utomo, 2013).

The development of social media use by the Indonesian people is very high, bringing the position of this country is the top 10 in the world rank beat the State in Southeast Asia, due to the high usage of internet media cause various problems especially easy to do crime, both cyberbullying crime, humiliation, fraud and hate speech done in the internet media.

The results of the explanation of the Republic of Indonesia's police regarding cyber-bullying crimes in Indonesia in the past two years have increased, the following is outlined.

\section{TABLE I.}

\section{CYBERBULLYING CRIME CASES IN INDONESIA}

\begin{tabular}{lll}
\hline $\begin{array}{l}\text { Type } \\
\text { Cybercrime }\end{array}$ & 2016 & 2017 \\
Cybercrime & 4,931 cases $^{\mathrm{a}}$ & 5,061 cases \\
\hline hate speech & 1,829 cases & 3,325 cases \\
\hline
\end{tabular}

${ }^{a}$ The development of cybercrime crime cases in Indonesia.

While the results of the report of the Director of Special Criminal Recesses of the Republic of Indonesia National Police in 2018 the number of cyber-bullying crime cases in the last three years has also increased, following the fig 1 .

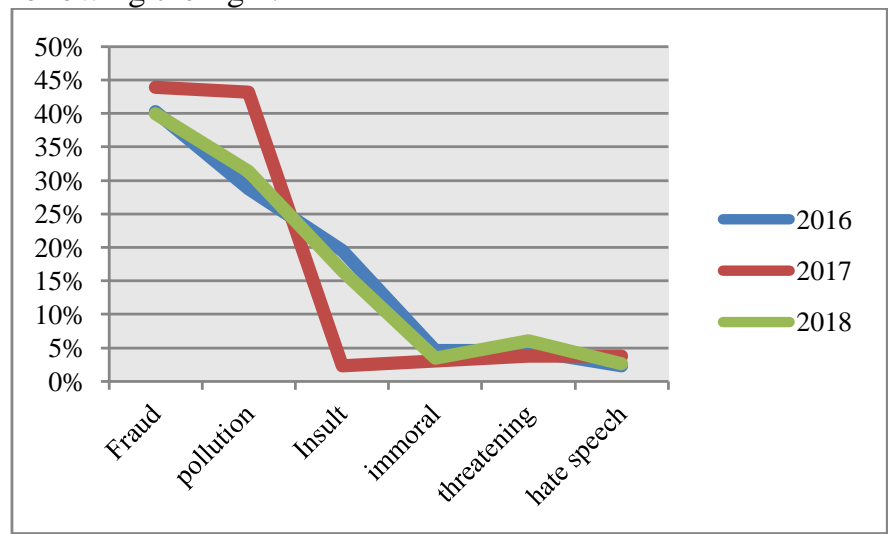

Fig 1: Number of cyber-bullying cases.

The case of cyber-bullying crime in figure 1 above shows that in the last three years cyber-bullying crime cases have fluctuated, wherein 2016 fraud cases through internet media reached $40 \%$, defamation $29 \%, 20 \%$ guidance, $5 \%$ obscenity, $5 \%$ threat, and $2 \%$ hate speech. In the year 2017 cases of fraud through the internet media has increased by $44 \%$, defamation $43 \%, 2 \%$ guidance, $3 \%$ immoral 3\%, 4\% threatening, and $4 \%$ hatred. While the year in 2018 cases of fraud through the internet media experienced a decline of $40 \%$, defamation $31 \%, 17 \%$ guidance, $3 \%$ immoral $3 \%, 6 \%$ threat, and $3 \%$ hatred.

Besides that, also explained the form of messages posted by the perpetrators against friends and or opponents play, here's an example.

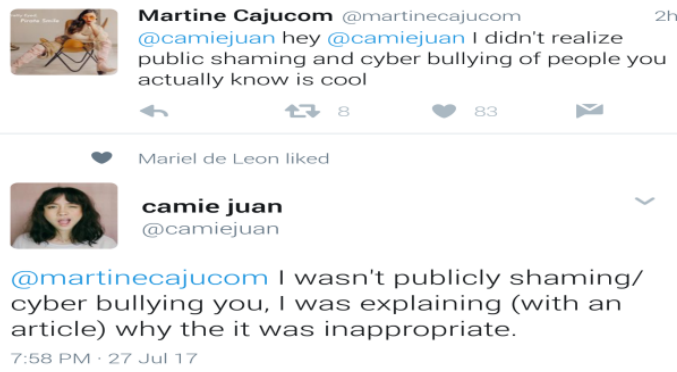

Fig 2. communication transactions mutually bullied on twitter.

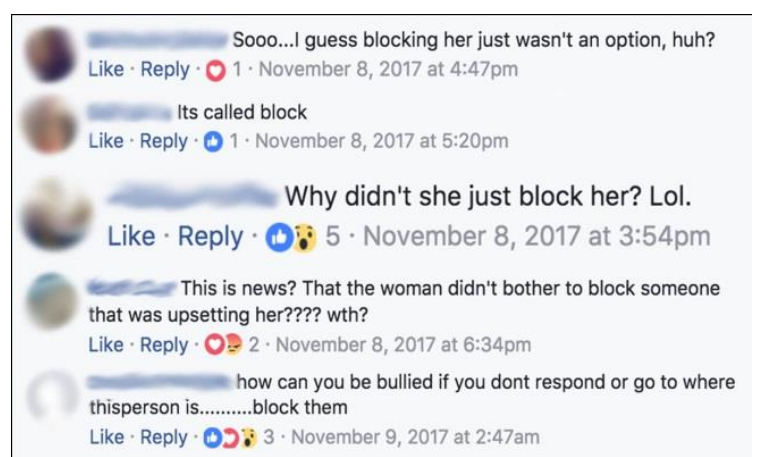

Fig 3. communication transactions mutually bullied on Facebook.

Various forms of cyber-bullying crime, in fact, has been a lot has been resolved by the police and academia in order to prevent and reduce cyber-bullying crime. The way it has been done is with the preemptive action of the police.

B. The role of the police in preventing cyber-bullying crimes in Indonesia

The role of the police in preventing cyber-bullying crimes in Indonesia is by conducting pre-emptive actions or early prevention efforts in the community through counseling and socialization and campaigning (Nasti, 2017). Similarly, the efforts made by police officers in tackling cyber-bullying is a preemptive effort. Preemptive efforts can be (1) the police held special training and vocational education carried out in collaboration between the National Police Criminal Investigation Agency and Information Technology experts, then conducted public outreach to the public regarding cybercrimes. (2) The establishment of International Cooperation in the eradication of cyber-bullying, and (3) Because of information and communication technology every decade changes, for that need to be done in using technology tool (Syam, 2015).

Thus, the police's preemptive action in preventing cyber-bullying can maximize the following ways:

1) provide counseling to students, college students, and the public about the dangers of caring for others by groups and individuals.

2) to adjust the rules to the articles of an article in the ITE legislation as follows:

a) respond to the complainant's claim that they can accommodate their aspirations

b) offer youths to be anti-cyber-bullying ambassadors. 
3) involves student organizations in anti-cyber-bullying campaigning, in addition to involving social organizations, youth organizations, professional organizations, and student organizations.

4) involving political parties that are able to provide education to the cadre the importance of using the internet media well.

5) strictly establish the perpetrators of title and cyberbullied.

6) program of art and creativity in the form of:

a) the competition to make anti-bullying posters

b) the competition to make anti-bullying scientific articles

7) impose sanctions and penalties of at least 5 years and maximum 10 years for cyber-bullying perpetrators in Indonesia.

In addition, it is necessary also how to ward off as early as possible so that no crime occurs, efforts to prevent the growth of evil desires and negate the factors that cause crime. So it needs to do activities such as improving the economy (unemployment, hunger, enhance civilization, and others (Lubis \& Sunarto, 2018).

How to prevent and reduce various cyber-bullying crimes in the internet media can maximize internet ethics, the role of parents more intensively, the police routinely conduct socialization activities and anti-bullying counseling, and social organizations.

1) Internet ethics (Netiquette)

Internet etiquette is an act of behavior of someone who is done through communication technology tools to convey messages and information both personal problems and group problems, with the communication tool that provides a positive and negative value for anyone who uses it. Internet communications ethics has the term Netiquette.

Netiquette is a code of ethics governing the way internet users in the move on the internet so that what is done does not violate the norms and applicable law so that internet facilities can be used properly without any party who harmed because of it (Surniandari, 2018). These guidelines work to direct and manage the interaction by providing comments and send messages on the internet on facebook, line, Instagram, email, and Twitter feature.

2) The role of parents

The role of parents is more intensive again in giving freedom to use the internet media. Some steps of parents in controlling the use of the internet media by their children, namely:

a) Provide more religious education

b) Providing time limits on using mobile and learning time

c) Control who social friends in social media

d) Have a child's social media account such as facebook, twitter, email, line and Instagram to facilitate checking every time

e) Provide an understanding of the importance of tolerating life in the internet media

f) Have a critical attitude towards the accounts in the Internet media indicated there is a message of contempt, threats, cyber-bullying and hate speech.
Similarly, other views, that parents need to strictly prohibit their children who are not old enough to be incorporated in social media like Facebook and Instagram. Internet users need to be adequately informed about internet etiquette or netiquette, various forms of cyber harassment, and the understanding that cyber account is something wrong (Rastati, 2016).

3) Police officers routinely conduct socialization activities and anti-bullying counseling in schools and communities

Socialization activities and anti-bullying counseling by civil police officers can be conducted in schools and communities.

a) School

School socialization activities are a form of police approach to providing early counseling to students about the dangers of cyber-bullying and simultaneously campaigning against bullying (stop bullying) among teenagers. The target schools are elementary, junior and senior high school.

For counseling activities conducted by providing training to teachers who have a closer relationship with students and students at the school. Because in the future they are in charge of assisting the police to become facilitators to identify cyber bullied crime, the impact of bullying on child development, early detection, reporting and handling of bullying both individual and systemic (Aliah B. Purwakania Hasan, Masni Erika Firmiana, Emmalia Sutiasamita, 2013).

b) Campus / institution

Socialization activities on the campus / agencies that have been implemented by the police to prevent cyberbullying is to be a resource person in national and international seminars conducted by universities, to lecturers and employees about the impacts of cyberbullying behavior, and to conduct study in one forum such as forum group discussion which deals specifically about cyber. Because the lecturer has the ability to know the symbols of cyber / techno bullying and they are also involved to handle the intervention of bullies and bullied (Glasner, 2010).

In addition, police also invite students and various student organizations to encourage monitoring together cyber-bullying crime and anti-bullying campaigning on campus by using posters, web campus with "stop cyber-bullying".

c) Society

The police effort in disseminating to the community is a direct approach with cafe managers through the government website (village/village, sub-district, and province) to post related messages about anti-cyberbullying and the impacts that occur to the victim cyberbullying and how to prevent it.

Prevention of cyber-bullying in the community is to recognize the character of the cyber-bullying agent, not easily believe the hoax news, not disseminate the hoax news to the public, investigate the truth of the hoax news, make complaints to the law enforcement authorities. 
To prevent cyber-bullying crime is not only the police but also the responsibility of other stakeholders including parents, schools, communities, law enforcement, and others. Each stakeholder has a duty to combat so that cyber-bullying can be prevented and stopped. For that also required cooperation from all related parties (Rahayu, 2012).

4) The role of social organization helps the police in preventing cyber-bullying crime

The role of social organizations in preventing cyberbullying is to pay attention to ethics in communicating, to deliver positive news in social media, to support each other, not to blaspheme each other, to be empathy toward others, and to be tolerant. Because bullying perpetrators do bullying due to having low empathy ability. The inability of the offender to empathize causes them to be less able to see from others' point of view, to recognize the feelings of others and to adjust their concerns appropriately. The lack of empathy from the perpetrators causes the perpetrator to be less understanding of the condition of the victim, regardless of the victim and tends to perform a sacrificial act on the victim (Rachmah, 2014).

5) The preemptive strategy of cyber-bullying in social media

The preemptive strategies of cyber-bullying on social media are as follows: (1) do not accept friend requests from strangers in social media and individuals often perform harassment in both the real and the cyber world (2) use filters or filters for emails, incoming calls on mobile phones, and SMS; (3) avoid uploading and submitting indecent images to anyone in the cyber world; (4) it is not advisable to convey all the information on the profile of the internet media so that there is no identity theft leading to the creation of fake accounts from irresponsible parties. (5) Do not be provoked to respond to anything on social media that leads to online fights and negative postings, and, (6) it is not recommended to notify the internet media password owned to anyone (Rastati, 2016).

The role of parents is also very important to control the behavior of children in the internet media, if the child has a twitter account, Facebook, Instagram and parent line should check the development of his child's account, this is done to avoid the existence of posts character of defamation, humiliation, fraud, other people. This is also true with some opinions explain that every parent needs to expressly prohibit children who are not old enough to be incorporated in social media like Facebook and Instagram. Internet users need to be adequately informed about internet etiquette or netiquette, various forms of cyberbullying, and the understanding that cyber-bullying is something wrong (Rastati, 2016).

That cyber-bullying in the internet media can find out the original identity of the internet media users and also know the contents of comments and conversations both offline and online. The results revealed that (1) the discussion on the account occurred in both directions from counter to pro to cyber-bullying and for some cases, this was proven, (2) there was a tendency to cyber-bullying through comments. (3) the interaction that occurred in cyber-bullying crime was done by 2 people with false identity (Nasrullah, 2015).

\section{CONCLUSION}

Indonesia is a country with very high social media users reaching 88.1 million people, so that it is prone to crime, based on the results of the study shows that there are various crimes committed by the Indonesian people through mass media including defamation, humiliation, hate speech and cyber-bullying.

The role of the police to reduce and prevent cyberbullying crime in Indonesia, can be done with the following steps: 1) socialization to educational institutions, institutions, campuses and the community on a regular basis, 2) maximizing the behavior of internet ethics, the role of parents should be more intensively supervise their children in use social media, civilian police officers routinely carry out "anti-bullying" campaigns in schools, and communities, and involve social organizations to monitor the circulation of cyber-bullying crime.

\section{ACKNOWLEDGMENT}

A sincere gratitude to the research team of inter-university research grantee "Andi Kasmawati", "Heri Tahir" and "Sahrul" which has helped to complete the writing of this article. Thanks also to the editor of this article who has provided many suggestions and inputs for the perfection of the article so that articles can be published. Thanks to the "Ministry of Research, Technology and the Higher Education Republic of Indonesia" as a sponsor in helping the writing of this scientific article.

\section{REFERENCES}

[1] Aliah B. Purwakania Hasan, Masni Erika Firmiana, Emmalia Sutiasamita, S. R. (2013). The effectiveness of Anti-Bullying Training on Knowledge of Handling of Bullying Cases in Schools in Jakarta Kindergarten Teachers, 2 (2), 81-88.

[2] Brack, K., \& Caltabiano, N. (2014). Cyberbullying and self-esteem in Australian adults. Cyberpsychology: Journal of Psychosocial Research on Cyberspace, $8(2)$.

[3] Crosslin, K., \& Crosslin, M. (2014). Cyberbullying at a Texas University-A Mixed Methods Approach to Examining Online Aggression. Texas Public Health Journal, 66(3).

[4] Glasner, A. T. (2010). On the Front Lines: Educating Teachers about Bullying and Prevention Methods. Journal of Social Sciences, 6(4), 537-541. https://doi.org/10.3844/jssp.2010.537.541

[5] Hinduja, S., \& Patchin, J. W. (2010). State cyberbullying laws: A brief review of state cyberbullying laws and policies. Cyberbullying Research Center.

[6] Hinduja, S., \& Patchin, J. W. (2014). Bullying beyond the Schoolyard: Preventing and responding to cyberbullying. Corwin Press.

[7] Indonesia, P. K. K. U. (2015). 2014 Indonesian Internet User Profile. Indonesian Internet Service Provider Association, March.

[8] Keller, M. (2012). Identifying and preventing cyberbullying among adolescents. Gonzaga University.

[9] Lubis, U. D. W. W. \& \& Sunarto, M. (2018). The Efforts of the Police in the Crime of Extortion and threats through Electronic Media (Studies in the Lampung Regional Police). Poenale Journal, 6 (1).

[10] Minin, A. R. (2018). The criminal policy against criminal acts of intimidation on the internet (Cyberbullying) as social media crime (cybercrime). LEGALITE, 2 (II), 1-18. 
[11] Nasrullah, R. (2015). Cyber-Bullying in the Facebook Status of the National Police Headquarters Public Relations Division. Sociotechnology Journal. Retrieved from http://journals.itb.ac.id/index.php/sostek/article/view/1359

[12] Nasti, B. (2017). Study of Criminology of Cyber Bullying Crime Through Facebook (Case Study of Dimas Yulian and Fajar Purnomo vs. Mawardi). Universitas Sebelas Maret.

[13] Pandie, M. M. I. T. J. W. (2016). Effect of Cyberbullying on Media, 14 (1).

[14] Rachmah, D. N. (2014). Empathy in the Bullying Actors. Ecopsy Journal, 1 (2), 51-58.

[15] Rahayu, F. S. (2012). Cyberbullying as a negative impact on the use of information technology. Journal of Information Systems, 8 (1), 22-31.

[16] Randa, R., Nobles, M., \& Reyns, B. (2015). Is Cyberbullying a Stand Alone Construct? Using Quantitative Analysis to Evaluate a 21st Century Social Question. Societies, 5(1), 171-186. https://doi.org/10.3390/soc5010171

[17] Rastati, R. (2016). Forms of Siberian Abuses in Social Media and Prevention for Victims and Perpetrators. Journal of Sociotechnology, 15 (2), 169-185.

[18] RI, T. P. H. K. P. (2014). Guide to Optimizing Social Media. Indonesian Ministry of Trade's Public Relations Center.

[19] Ryan, K. N., \& Curwen, T. (2013). Cyber-victimized students: Incidence, impact, and intervention. SAGE Open, 3(4). https://doi.org/10.1177/2158244013516772

[20] Selkie, E. M., Kota, R., Chan, Y.-F., \& Moreno, M. (2015). Cyberbullying, depression, and problem alcohol use in female college students: a multisite study. Cyberpsychology, Behavior, and Social Networking, 18(2), 79-86.

[21] Sittichai, R. (2013). Bullying and Cyberbullying in Thailand: a Review. International Journal of Cyber Society and Education, 6(1), 31-44. https://doi.org/10.7903/ijcse.1032

[22] Surniandari, A. (2018). Hate speech as a Violation of Internet Ethics and Communicating on Social Media. Symposium 2017, 1 (1), $137-142$.

[23] Syam, A. A. (2015). Criminological Review of Cyberbullying Crimes. Hasanuddin University Makassar. Retrieved from https://scholar.google.co.id.

[24] Utomo, D. A. (2013). The motive of Google+ social networking users in Indonesia. Journal of E-Communication, 1 (3).

[25] Walker, C. M., Sockman, B. R., \& Koehn, S. (2011). An exploratory study of cyberbullying with undergraduate university students. TechTrends, 55(2), 31-38. 